\title{
A Kobayashi- és a Kawanet-pontrendszer prediktív értéke Kawasaki-kóros betegeink immunglobulin-rezisztenciája és kardiológiai szövődményei szempontjából
}

\author{
Pilotvizsgálat
}

\author{
Vágó Ildikó dr. - Guóth Gábor dr. \\ id. Simon Gábor dr. - Szabó Hajnalka dr.
}

Fejér Megyei Szent György Egyetemi Oktató Kórház, Újszülött-, Csecsemő- és Gyermekosztály, Székesfehérvár

\begin{abstract}
Bevezetés: A Kawasaki-szindróma immunvasculitis, amely kezeletlenül kardiológiai szövődményekhez vezethet. A korai intravénás immunglobulin-terápia mérsékli a szövődményeket, de az esetek 10-20\%-a rezisztens a kezelésre. Ennek előrejelzésére világszerte számos rizikóbecslő pontrendszert használnak.

Célkitüzés: A Kobayashi- és a Kawanet-pontrendszer prediktív értékének vizsgálata betegeink intravénás immunglobulin-rezisztenciája és kardiológiai szövődményei vonatkozásában. Tudomásunk szerint ez az első magyarországi vizsgálat, amely Kawasaki-szindróma esetében pontrendszerek prediktív értékét méri fel.

Módszer: Retrospektív pilotvizsgálatunkban kigyújtöttük a 2005. január és 2020. április között Kawasaki-szindróma miatt ápolt betegeink adatait. Mindegyiküknél Kobayashi-, illetve Kawanet-pontot számoltunk, valamint megvizsgáltuk azok specificitását, szenzitivitását az intravénás immunglobulin-rezisztencia, illetve a kardiológiai szövődmények előrejelzése szempontjából. A Kobayashi-pontrendszerben 4, a Kawanet-pontrendszerben pedig 2 pont vagy annál magasabb érték jelez rizikót.

Eredmények: Kawasaki-szindrómát 28 gyereknél véleményeztünk, 13 esetben észleltünk mérsékelt, 4 esetben súlyos szövődményt. 4 betegünk bizonyult intravénás immunglobulinra rezisztensnek. A rezisztencia szempontjából a Kobayashi-pontrendszer alacsony szenzitivitást $(25 \%)$, illetve magas specificitást $(91,6 \%)$, míg a Kawanet-pontrendszer mérsékelt szenzitivitást (50\%) és specificitást (50\%) mutatott. A szövődmények szempontjából hasonló eredményeket kaptunk, Kobayashi-pontrendszer: szenzitivitás: 17\%; specificitás: 100\%, illetve Kawanet-pontrendszer: szenzitivitás: $47 \%$; specificitás: $45 \%$.

Következtetés: A legtöbb, nem ázsiai országban készült tanulmányhoz hasonlóan az intravénás immunglobulin-rezisztencia előrejelzésében a Kobayashi-pontrendszer vizsgálatunkban sem bizonyult hatékonynak. Ezzel szemben, magasabb szenzitivitása miatt, a Kawanet-pontrendszer intravénás immunglobulin-rezisztenciát előre jelző hatékonyságát érdemes lenne nagyobb esetszámban vizsgálni a hazai populációban is. A kardiológiai szövődmények előrejelzésére egyik pontrendszer sem bizonyult alkalmasnak.
\end{abstract}

Orv Hetil. 2021; 162(47): 1885-1890.

Kulcsszavak: Kawasaki-szindróma, IVIG-kezelés, rizikóbecslés, kardiológiai szövődmények

The predictive value of the Kobayashi and Kawanet score systems regarding immunoglobulin resistance and cardiac complications in patients with Kawasaki disease

A pilot study

Introduction: Kawasaki disease is an immunovasculitis, which, without treatment, leads to cardiac complications. Early intravenous immunoglobulin therapy moderates complications, however, $10-20 \%$ of patients are resistant to the therapy. Numerous risk score systems are used worldwide to predict this.

Objective: To assess the predictive value of the Kobayashi and Kawanet score systems regarding intravenous immunoglobulin resistance and cardiac complications in our department's patient cohort. To our best knowledge, this is the first study in Hungary, which examines the predictive value of score systems in the case of Kawasaki disease. 
Method: In our study, we identified the patients treated for Kawasaki disease between January 2005 and April 2020. In each case, we calculated both the Kobayashi and the Kawanet score, and we examined their specificity and sensitivity regarding the prediction of intravenous immunoglobulin resistance and cardiac complications. In the Kobayashi score system, values above 4 , in the Kawanet score system, values above 2 signal risk.

Results: We identified 28 patients with Kawasaki disease. We observed moderate complications in 13, severe complications in 4 cases. 4 of our patients were resistant to intravenous immunoglobulin therapy. Regarding intravenous immunoglobulin resistance in our patient cohort, we detected low sensitivity (25\%) and high specificity $(91.6 \%)$ in the case of Kobayashi score, and moderate sensitivity (50\%) and specificity (50\%) in the case of Kawanet score. Regarding complications, we found similar results in the case of Kobayashi (sensitivity: 17\%; specificity: 100\%) and the Kawanet (sensitivity: $47 \%$; specificity: $45 \%$ ) score system.

Conclusion: Similarly to the majority of non-Asian studies, we found the Kobayashi score system ineffective in predicting intravenous immunoglobulin resistance. However, due to its higher sensitivity, the predictive value of the Kawanet score system regarding intravenous immunoglobulin resistance is worth examining in a larger patient population in Hungary. Regarding the prediction of cardiac complications, both score systems were found to be ineffective.

Keywords: Kawasaki-disease, IVIG therapy, risk score, cardiac complications

Vágó I, Guóth G, Simon G Sr, Szabó H. [The predictive value of the Kobayashi and Kawanet score systems regarding immunoglobulin resistance and cardiac complications in patients with Kawasaki disease. A pilot study]. Orv Hetil. $2021 ; 162(47): 1885-1890$.

(Beérkezett: 2021. április 1.; elfogadva: 2021. május 4.)

\section{Rövidítések}

ASA = acetilszalicilsav; BNO = Betegségek Nemzetközi Osztályozása; $\mathrm{CRP}=\mathrm{C}$-reaktív protein; GOT = glutamát-oxálacetát transzamináz; GPT = glutamát-piruvát-transzamináz; IVIG = intravénás immunglobulin

A Kawasaki-szindróma világszerte előforduló, akut, önkorlátozó, elhúzódó lázzal járó szisztémás immunvasculitis. Etiológiája jelenleg még ismeretlen, genetikai és környezeti faktorok együttes hatása játszik benne szerepet. A Henoch-Schönlein-purpura után a második leggyakoribb gyulladásos érelváltozás gyermekkorban [1]. A tünetek nem specifikusak, a minimum 5 napig tartó lázas állapot mellett az 5 fó klinikai jelból legalább 4 megléte a Kawasaki-szindróma mellett szól [2]. Abban az esetben, ha az elhúzódó láz mellett <4-nél tünet jelenik meg, vagy a láz és a jellemző laboratóriumi eltérések mellett echokardiográfiával igazolt koszorúér-érintettség is látható, inkomplett Kawasaki-szindrómáról beszélhetünk [1]. A kezeletlen esetek súlyos cardialis szövődményekhez vezethetnek (myocarditis, koszorúér-aneurizma, thrombosis, myocardialis infarctus) [3]. Mérsékelt cardialis szövődmények is előfordulhatnak, például koszorúér-tágulat vagy pericardialis folyadék képződése. Fejlett országokban a gyermekkori szerzett szívbetegségek leggyakoribb oka [4]. 1 évesnél fiatalabb és 5 évnél idősebb életkorban ritkán fordul elő, ilyenkor azonban gyakrabban kell szövődményekkel számolnunk. A betegség előfordulása kiemelkedően magas az ázsiai gyermekek körében, ami alátámasztja a genetikai prediszpozíció jelentőségét [2].
A korai intravénás immunglobulin (IVIG)- és acetilszalicilsav (ASA)-terápia segít a szövődmények számának csökkentésében. Az esetek 10-20\%-ában viszont a kezelés hatástalansága figyelhető meg [5]. IVIG-rezisztencián az immunglobulin-terápiát követő, 36 órát meghaladó vagy 36 órán belül visszatérő lázas állapotot értjük, előrejelzésére világszerte számos pontrendszert használnak $[5,6]$. Ezek jelentősége abban áll, hogy segítségükkel korán ki tudjuk szürni az IVIG-rezisztens eseteket, akkor a szteroiddal kombinált IVIG-terápia csökkentheti a súlyos szövődmények valószínûségét.

Vizsgálatunk célja, hogy megállapítsuk a Kobayashiés a Kawanet-pontrendszer prediktív értékét, egyrészt az IVIG-rezisztencia, másrészt a cardialis szövődmények vonatkozásában, osztályunk beteganyagában. Legjobb tudomásunk szerint ez az első magyarországi vizsgálat, amely a Kawasaki-szindróma esetében pontrendszerek prediktív értékét méri fel.

\section{Módszer}

Retrospektív pilotvizsgálatunkban (kis létszámú elővizsgálat) a kórházunkban használatos elektronikai betegellátó rendszerben (MedSolution) a BNO-kódrendszer alapján a „mucocutan nyirokcsomó syndroma [Kawasaki]" betegségnek megfelelő kód (M3030) segítségével kiszürtük a 2005. január 1. és 2020. április 30. között osztályunkon ezzel a diagnózissal ápolt betegeket. Ezt követően adataik alapján, diagnózisukat az American Heart Association által felállított kritériumok alapján revideáltuk [2]. Minden betegnél Kobayashi-, illetve Kawanet-pontot számoltunk, és megvizsgáltuk ezek spe- 
1. táblázat

A Kobayashi- és a Kawanet-rizikóbecslés

Kobayashi-pontrendszer

\begin{tabular}{lll}
\hline Változó & Határérték & Pont \\
\hline Nátriumszint & $\leq 133 \mathrm{mmol} / 1$ & 2 \\
$\begin{array}{l}\text { A terápia kezdetéig eltelt lázas napok } \\
\text { száma }\end{array}$ & $\leq 4$ nap & 2 \\
GOT & $\geq 100 \mathrm{IU} / 1$ & 2 \\
$\%$ neutrofil & $\geq 80 \%$ & 2 \\
CRP & $\geq 100 \mathrm{mg} / 1$ & 1 \\
Kor & $\leq 12$ hó & 1 \\
Thrombocytaszám & $\leq 30,0 \times 10^{4} / \mathrm{mm}^{3}$ & 1 \\
\hline Kawanet-pontrendszer & & \\
\hline Változó & Határérték & Pont \\
\hline GPT-szint & $>30 \mathrm{U} / 1$ & 1 \\
Hepatomegalia & & 1 \\
Lymphocytaszám & $<2400 / \mathrm{mm}^{3}$ & 1 \\
A terápia kezdetéig eltelt lázas napok & $<5$ nap & 1 \\
száma & &
\end{tabular}

CRP = C-reaktív protein; GOT = glutamát-oxálacetát-transzamináz; GPT = glutamát-piruvát-transzamináz

cificitását, szenzitivitását az IVIG-rezisztencia, illetve a cardialis szövődmények kialakulásának szempontjából (1. táblázat). Abban az esetben, ha a terápia kezdete előtt több laboratóriumi vizsgálat is történt, a legmagasabb (GOT, neutrofil százalékos arány, CRP-szint), illetve a legalacsonyabb (nátriumszint, thrombocyta-, valamint lymphocytaszám) értéket vettük figyelembe. A betegség kezdetének az első lázas napot tartottuk. A Kobayashi-pontrendszerben a $>4$, a Kawanet-pontrendszerben pedig a $>2$ pontszám jelez rizikót $[5,6]$.

A nyert adatok alapján vizsgáltuk a lázas állapot kezdetétól és az osztályos felvételtől a terápia elkezdéséig eltelt napok számát, ezek összefüggését a szövődmények kialakulásával, valamint a kórházi tartózkodás időtartamával.

Az IVIG-kezelés a nemzetközi standardnak megfelelöen egyszeri $2 \mathrm{~g} / \mathrm{ttkg}$ adagban történt; 2010 előtt 3 esetben a fenti dózist 4 , illetve 5 nap alatt egyenlő részletekre elosztva adtuk be $[1,7]$. Betegeink minden esetben az akut szakban magas dózisú (80-100 mg/ttkg, 4 részre elosztva) ASA-kezelésben is részesültek a láz megszűnését követően 48-72 óráig.

\section{Eredmények}

\section{Demográfiai adatok}

A BNO-kód alapján történt lekérdezés során összesen 31 eset felelt meg az elsődleges szûrési kritériumoknak; a diagnózisok revideálását követően végül 28 gyereknél véleményeztük a Kawasaki-szindróma definitív diagnózisát.

\section{Szövödmények}

22 esetben a betegség komplett, 6 esetben inkomplett formáját állapítottuk meg. Az akut szakaszban történt kardiológiai vizsgálatok áttekintése alapján összesen 17 esetben (60\%) lépett fel szövődmény (2. táblázat). A szövődmény 13 betegnél mérsékelt fokú és reverzibilis volt, a betegek tünet- és panaszmentessé váltak legkésőbb 1 hónapon belül. A súlyos szövődmények közül koszorúér-aneurizmát 4 esetben (14\%) észleltünk.

Egy 3 hónapos, 14 napja lázas betegünknél már felvételkor súlyos fokú coronariadilatatiót és pericarditist észleltünk. Országos intézetben később elvégzett koronarográfia igazolta az ultrahangos diagnózist: a jobb koszorúéren óriás aneurizmát, míg a bal koszorúéren gyöngyfüzérszerú tágulatokat mutatott ki. A terápia (kumarin, ASA) mellett az aneurizmák ugyan mind a jobb,

2. táblázat |A klinikai jellemzők megoszlása szövődményes és szövődménymentes esetekben

\begin{tabular}{|c|c|c|c|}
\hline Változó & $\begin{array}{l}\text { Teljes Kawasaki-szind- } \\
\text { rómás populáció } \\
(\mathrm{n}=28)\end{array}$ & $\begin{array}{l}\text { Szövődménymentes } \\
\qquad(\mathrm{n}=11)\end{array}$ & $\begin{array}{l}\text { Szövődményes } \\
(\mathrm{n}=17)\end{array}$ \\
\hline Nemi eloszlás (f/n) & $17 / 11$ & $6 / 5$ & $11 / 6$ \\
\hline A kórházi felvételt megelőző lázas napok száma & 5,27 (1 és 14) & 4,2 (1 és 6) & 6,1 (3 és 14) \\
\hline A tünetek megjelenésétől az IVIG-kezelésig eltelt napok száma & 7,53 (4 és 16) & 6 (4 és 11) & 9 (5 és 16) \\
\hline A kórházi felvételtől az IVIG-kezelésig eltelt napok száma & 2,4 (0 és 9) & 2,1 (0 és 7) & 2,75 (0 és 9) \\
\hline A kórházi napok száma & 11,16 (4 és 24) & 9 (4 és 16) & 13 (6 és 24) \\
\hline IVIG-rezisztencia & $4(14 \%)$ & 2 & 2 \\
\hline \multicolumn{4}{|l|}{ Klinikai manifesztációk } \\
\hline Exanthema & 22 & 8 & 14 \\
\hline Nyaki nyirokcsomó-megnagyobbodás & 17 & 5 & 12 \\
\hline Nonpurulens kötőhártya-gyulladás & 26 & 11 & 15 \\
\hline Szájnyálkahártya-eltérés & 13 & 7 & 6 \\
\hline
\end{tabular}

IVIG = intravénás immunglobulin 
mind a bal koszorúéren regrediáltak, azonban a bal anterior descendens ágon az eredésnél teljes elzáródás jött létre, mely jelenleg a kollaterálisok útján, a korábban aneurizmás jobb koszorúér felől kapja a vérellátást, így szívizomelhalás nem történt.

A másik 3 beteg esetében, akiknél súlyos szövődmény alakult ki, az akut szakaszban észlelt koszorúér-aneurizmák fél év alatt teljes mértékben regrediáltak.

\section{Kezelés}

A vizsgált időszakban minden Kawasaki-szindrómás betegünk IVIG-kezelésben részesült. Az alkalmazott standard terápia mellett 23 betegünk 36 órán belül láztalanná vált, 4 páciens IVIG-rezisztens volt: náluk IVIG-ismétlés történt, közülük óriás aneurizmás betegünk kiegészítő kortikoszteroidterápiát is kapott.

A lázas állapot kezdete után minél korábban elkezdett IVIG- és ASA-terápia csökkentette a szövődmények kialakulásának valószínúségét, ezáltal a kórházban töltött napok számát is (2. táblázat).

\section{Kobayashi-és Kawanet-pontrendszer}

A 28 páciensnek a Kobayashi-, illetve a Kawanet-pontrendszer alapján történő besorolását, valamint a pontrendszerek specificitását és szenzitivitását beteganyagunkra nézve a 3. táblázat tartalmazza.

\section{Megbeszélés}

Jelen tanulmányunk az első magyarországi vizsgálat, amely célzottan az IVIG-rezisztencia előrejelzésére született rizikóbecslések hatékonyságát vizsgálta hazai populációban $[8,9]$.

Vizsgálatunk során az elmúlt 15 évben osztályunkon Kawasaki-szindrómával kezelt 28 beteg adatait tekintettük át. Az irodalmi adatoknak megfelelően betegeink többsége az 1-5 éves közötti korosztályból került ki [2]. A 4, 12 hónapnál fiatalabb betegünk közül három esetében jelent meg cardialis szövődmény, a legsúlyosabb betegünk is 1 év alatti volt. Megfigyelhettük továbbá azt az irodalomban korábban már alátámasztott összefüggést, hogy az 1 évesnél fiatalabb betegek esetében gyakrabban kell számolni IVIG-rezisztenciával és súlyosabb cardialis

3. táblázat |A Kobayashi- és a Kawanet-rizikóbecslés szenzitivitása és specificitása a vizsgált populációban

\begin{tabular}{l|c|c|c|c}
\hline & \multicolumn{2}{|c|}{ Kobayashi-pontrendszer } & \multicolumn{2}{c}{ Kawanet-pontrendszer } \\
\cline { 2 - 5 } & Szenzitivitás & Specificitás & Szenzitivitás & Specificitás \\
\hline IVIG-rezisztencia & $25 \%$ & $91,6 \%$ & $50 \%$ & $50 \%$ \\
Cardialis & $17 \%$ & $100 \%$ & $47 \%$ & $45 \%$ \\
szövődmények & & & & \\
\hline
\end{tabular}

IVIG = intravénás immunglobulin szövődménnyel [10]. Ezért a nemzetközi ajánlások javasolják a szisztémás kortikoszteroid kezdeti, IVIG-terápiával együtt történő bevezetését 12 hónapos kor alatt $[1,6,11,12]$.

$\mathrm{Az}$ irodalomban leírt téli-tavaszi szezonalitás a mi vizsgálati csoportunkban nem volt detektálható, az enyhe férfidominanciát azonban mi is észleltük [2].

A Kawasaki-szindróma kezeletlen esetekben akár 25\%-ban súlyos szövődményekhez vezethet, az időben megkezdett IVIG-terápia azonban az aneurizmának és az egyéb súlyos cardialis szövődményeknek az előfordulását 4\%-ra csökkentheti [2]. Az irodalmi adatokkal megegyezően a korán alkalmazott standard terápia nálunk is kedvezően befolyásolta a szövődmények gyakoriságát, illetve a kórházi tartózkodás időtartamát [13]. Vizsgálatunkban súlyos szövődmények az irodalomban olvasható 10\%-nál gyakrabban, összesen 14\%-ban jelentkeztek, közülük az egyik óriás aneurizma volt koszorúér-stenosissal és pericarditisszel. Az esetünkben megfigyelt kórlefolyás az irodalomban olvasottakhoz hasonló, mivel óriás aneurizma esetén szinte soha nem várható teljes regresszió [1]. A másik 3, súlyos cardialis érintettséggel kezelt betegünknél az aneurizmák teljes regresszióját figyeltük meg fél éven belül, amely arány kiemelten jó az irodalomban szereplő adatokhoz képest, ahol 1-2 éven belül az esetek 50-70\%-ában számolnak be teljes gyógyulásról [1].

A megfelelő kezelés ellenére a betegek 10-20\%-ánál észlelhető IVIG-rezisztencia az irodalom szerint, náluk nagyobb az esély a súlyos koszorúér-szövődmények megjelenésére is [5]. Betegeink között 4 gyermeknél (14\%) tapasztaltunk IVIG-rezisztenciát; a súlyos cardialis szövődmények fele is közülük került ki, ami az irodalmi adatoknak is megfelel. IVIG-rezisztens esetekben a terápia kortikoszteroiddal történő kiegészítésével csökkenthető a súlyos cardialis szövődmények száma [2].

\section{A Kobayashi-pontrendszer}

Az IVIG-rezisztencia előrejelzésének érdekében több pontrendszert is kifejlesztettek, nagy részüket ázsiai populációban végzett vizsgálatok alapján. Közülük a 2006ban publikált Kobayashi-rizikórendszer a legmegbízhatóbb és legelterjedtebb [5]. Előnye, hogy objektív laboratóriumi és klinikai paramétereket használ a számításhoz. Hátránya, hogy ázsiai populáció adatai alapján készítették, és nem ázsiai betegeknél a szenzitivitása alacsony, negatív prediktív értéke nem megfelelő $[4,10$, 14]. Többen vizsgálták a pontrendszer szenzitivitását, közülük a legismertebb a RAISE-tanulmány, amely a Japánban kezelt betegek IVIG-rezisztenciáját és a kiegészítő kortikoszteroidterápia hatékonyságát elemezte [15]. A tanulmány szerint a pontrendszer alkalmas a rezisztencia kiszűrésére, és ez alapján a már primeren használt kiegészítő kortikoszteroidterápiával csökkenthető a súlyos szövődmények száma. Egy Törökországból publikált friss tanulmány is szenzitívnek találta a hagyományos 


\begin{tabular}{|c|c|c|c|c|c|}
\hline Cardialis manifesztáció & $\begin{array}{c}\text { Teljes Kawasaki- } \\
\text { szindrómás populáció } \\
(\mathrm{n}=28)\end{array}$ & $\begin{array}{c}\text { Kobayashi-pontszám } \\
\qquad 4 \\
(\mathrm{n}=3)\end{array}$ & $\begin{array}{c}\text { Kobayashi-pontszám } \\
\qquad \begin{array}{c}<4 \\
(\mathrm{n}=25)\end{array}\end{array}$ & $\begin{array}{c}\text { Kawanet-pontszám } \\
\begin{array}{c}\geq 2 \\
(\mathrm{n}=14)\end{array}\end{array}$ & $\begin{array}{c}\text { Kawanet-pontszám } \\
<2 \\
(\mathrm{n}=14)\end{array}$ \\
\hline Szövődménymentes & $11(39 \%)$ & $0(0 \%)$ & $11(44 \%)$ & $6(43 \%)$ & $5(36 \%)$ \\
\hline Koszorúér-dilatatio & $4(14 \%)$ & $0(0 \%)$ & $4(16 \%)$ & $3(22 \%)$ & $1(7 \%)$ \\
\hline Pericardialis folyadék & $5(18 \%)$ & $1(33 \%)$ & $4(16 \%)$ & $2(14 \%)$ & $3(22 \%)$ \\
\hline $\begin{array}{l}\text { Koszorúér-dilatatio és } \\
\text { pericardialis folyadék }\end{array}$ & $4(14 \%)$ & $2(67 \%)$ & $2(8 \%)$ & $3(22 \%)$ & $1(7 \%)$ \\
\hline Aneurizma & $4(14 \%)$ & $0(0 \%)$ & $4(16 \%)$ & $0(0 \%)$ & $4(29 \%)$ \\
\hline IVIG-rezisztencia & $4(14 \%)$ & $1(33 \%)$ & $3(12 \%)$ & $2(14 \%)$ & $2(14 \%)$ \\
\hline
\end{tabular}

IVIG = intravénás immunglobulin

terápiával szemben rezisztens esetek kiszúrésére [16]. Ezzel szemben több európai országban és az Egyesült Államokban végzett vizsgálat szerint szenzitivitása a kaukázusi populációra nézve nem megfelelő [4, 14, 17].

A 4 vagy magasabb, kockázatot jelző Kobayashi-pontszámot elérő betegeink mindegyikénél kialakult cardialis szövődmény, ám a súlyos eltérésekkel szövődött esetek mindegyike a 4 alatti pontszámot elérő csoportból került ki. A Kobayashi-pontrendszer tehát a szövődmények vonatkozásában rizikóbecslésre nem bizonyult alkalmasnak. IVIG-rezisztencia mindkét csoportban előfordult: 4 és a feletti Kobayashi-pontszám esetén 66\%-ban, míg 4 alatti pontszám esetén 12\%-ban tapasztaltuk. A Kobayashi-pontrendszer specificitása az IVIG-rezisztencia előrejelzésére vizsgálatunk alapján megfelelőnek tűnik, tehát alacsony pontszámot elérő betegeink esetén valóban kis eséllyel jelentkezett IVIG-rezisztencia. A teszt szenzitivitása azonban alacsonynak bizonyult a betegpopulációnkon, tehát a magas pontszám nem megfelelő bizonyossággal szúri ki a valóban IVIG-rezisztens betegeket. Ezek alapján a Kobayashi-pontrendszer kaukázusi populációban rizikóbecslésre a mi adataink alapján sem bizonyult alkalmasnak (3. táblázat).

\section{A Kawanet-pontrendszer}

A Kobayashi-pontrendszer gyenge szenzitivitása a nem ázsiai Kawasaki-szindrómás populációban odavezetett, hogy többek között a Maryam Piram vezette francia kutatócsoport kísérletet tett európai betegpopuláción is használható, IVIG-rezisztenciát előre jelző pontrendszer kidolgozására (Kawanet-pontrendszer) [6]. Ezen rizikóbecslés klinikai (hepatomegalia, a kezelés kezdete), valamint laboratóriumi (GPT, lymphocytaszám) paramétereket vett alapul. A módszer szenzitivitása multietnikus populáción vizsgálva $77 \%$, míg specificitása $60 \%$ volt, ami hatékonyabbnak bizonyult az ugyanezen a beteganyagon számolt Kobayashi-pontrendszer szerinti 61\%-nál, illetve 68\%-nál. Az európai kaukázusi etnikumhoz tarto- zó beteganyagot tekintve a módszer szenzitivitása 74\%, specificitása $57 \%$ volt.

Beteganyagunkat áttekintve a Kawanet-pontrendszer szerint 2 vagy a feletti, illetve alatti pontszámot elérő betegek között nem volt eltérés a szövődmények megjelenésének gyakoriságában. Súlyos cardialis érintettséggel (aneurizma) szövődött betegeink azonban itt is a 2 alatti pontszámú csoportból kerültek ki. IVIG-rezisztenciát a 2 és a feletti, illetve alatti pontszámú csoportban 1414\%-ban észleltünk (4. táblázat).

Adataink alapján a Kawanet-pontrendszer specificitása és szenzitivitása 50-50\% volt az IVIG-rezisztenciára nézve. Ez elmarad ugyan az eredeti tanulmányban ismertetett értékektől, a Kobayashi-rizikóbecslésnél azonban szenzitívebbnek tûnik beteganyagunkat tekintve. Ennek pontosabb vizsgálatára nagyobb esetszámú tanulmányok lennének szükségesek. Vizsgálatunk gyenge pontja az, hogy esetszámunk kevés ahhoz, hogy statisztikailag megalapozott, messzemenő következtetéseket lehessen levonni a Kawasaki-szindrómában szenvedő magyar populációra nézve. A súlyos szövődmények előrejelzésére a pontrendszerek nem bizonyultak alkalmasnak.

\section{Következtetés}

Retrospektív pilotvizsgálatukban a Kobayashi- és a Kawanet-pontrendszer prediktív értékét vizsgáltuk az elmúlt 15 évben osztályunkon kezelt, Kawasaki-szindrómás betegeink IVIG-rezisztenciája és cardialis szövődményei szempontjából. A legtöbb nem ázsiai tanulmányhoz hasonlóan az IVIG-rezisztencia előrejelzésében a Kobayashi-pontrendszer az általunk vizsgált populációban sem bizonyult hatékonynak. Ezzel szemben, magasabb szenzitivitása miatt, a Kawanet-pontrendszer IVIGrezisztenciát előre jelző hatékonyságát érdemes lenne nagyobb esetszámon vizsgálni a hazai populációban. A várható cardialis szövődmények előrejelzésére egyik pontrendszer sem bizonyult alkalmasnak vizsgálatunkban. 
Anyagi támogatás: A szerzók anyagi támogatásban nem részesültek.

Szerzői munkamegosztás: Az eredeti ötlet: Sz. H. A kézirat megírásában V. I. és G. G. egyenlő mértékben vett részt. Irodalomkutatás: V. I., Sz. H. Adatgyưjtés: V. I. Adatbevitel, adatelemzés: V. I., G. G. A kézirat ellenőrzése, végső formába öntése: Sz. H., id. S. G. A cikk végleges változatát valamennyi szerző elolvasta és jóváhagyta.

Érdekeltségek: A szerzőknek nincsenek érdekeltségeik.

\section{Köszönetnyilvánítás}

Köszönjük $d r$. Mayer Gizella és $d r$. Simon Kornélia gyermekkardiológus főorvosok értékes segítségét a Kawasaki-szindrómás betegek kardiológiai szövődményeire vonatkozó adatok szolgáltatásában. Külön köszönetünket fejezzük ki ifj. dr. Simon Gábor kardiológus föorvosnak a Gottsegen Országos Kardiológiai Intézetből a súlyos óriás aneurizmás betegünk utánkövetéséről szóló adatszolgáltatásért és szakmai tanácsaiért.

\section{Irodalom}

[1] Eleftheriou D, Levin M, Shingadia D, et al. Management of Kawasaki disease. Arch Dis Child. 2014; 99: 74-83.

[2] McCrindle BW, Rowley AH, Newburger JW, et al. Diagnosis, treatment, and long-term management of Kawasaki disease: a scientific statement for health professionals from the American Heart Association. Circulation 2017; 135: e927-e999.

[3] Sano T, Kurotobi S, Matsuzaki K, et al. Prediction of nonresponsiveness to standard high-dose gamma-globulin therapy in patients with acute Kawasaki disease before starting initial treatment. Eur J Pediatr. 2007; 166: 131-137.

[4] Fabi M, Andreozzi L, Corinaldesi E, et al. Inability of Asian risk scoring systems to predict intravenous immunoglobulin resistance and coronary lesions in Kawasaki disease in an Italian cohort. Eur J Pediatr. 2019; 178: 315-322.

[5] Kobayashi T, Inoue Y, Takeuchi K, et al. Prediction of intravenous immunoglobulin unresponsiveness in patients with Kawasaki disease. Circulation 2006; 113: 2606-2612.
[6] Piram M, Darce Bello MD, Tellier S, et al. Defining the risk of first intravenous immunoglobulin unresponsiveness in non-Asian patients with Kawasaki disease. Sci Rep. 2020; 10: 3125.

[7] Newburger JW, Takahashi M, Beiser AS, et al. A single intravenous infusion of gamma globulin as compared with four infusions in the tretment of acute Kawasaki syndrome. N Engl J Med. 1991; 324: 1633-1639.

[8] Berzicza E, Simon G jr, Simon G. The Kawasaki syndrome and its cardiological consequences in our ward during a three-year period. [A Kawasaki-szindróma és kardiológiai vonatkozásai osztályunkon hároméves időtartam alatt.] Gyermekgyógyászat 2014; 65: 399-403. [Hungarian]

[9] Tróbert-Sipos D. The practice of the therapy of Kawasaki disease in Hungary. [A Kawasaki-betegség kezelésének hazai gyakorlatáról.] Available from: http://www.infektologia.hu/upload/infektologia/document/a_kawasaki_betegseg_hazai_kezelesenek_ gyakorlatarol.pdf [accessed: March 31, 2021]. [Hungarian]

[10] Tulloh RM, Mayon-White R, Harnden A, et al. Kawasaki disease: a prospective population survey in the UK and Ireland from 2013 to 2015. Arch Dis Child. 2019; 104: 640-646.

[11] Jaggi P, Wang W, Dvorchik I, et al. Patterns of fever in children after primary treatment for Kawasaki disease. Pediatr Infect Dis J. 2015; 34: 1315-1318.

[12] Sevenoaks L, Tulloh R. Should we use steroids as primary therapy for Kawasaki disease? Arch Dis Child. 2020; 105: 1120-1124.

[13] Li X, Chen Y, Tang Y, et al. Predictors of intravenous immunoglobulin-resistant Kawasaki disease in children: a meta-analysis of 4442 cases. Eur J Pediatr. 2018; 177: 1279-1292.

[14] Jakob A, von Kries R, Horstmann J, et al. Failure to predict highrisk Kawasaki disease patients in a population-based study cohort in Germany. Pediatr Infect Dis J. 2018; 37: 850-855.

[15] Kobayashi T, Saji T, Otani T, et al. Efficacy of immunoglobulin plus prednisolone for prevention of coronary artery abnormalities in severe Kawasaki disease (RAISE study): a randomised, open-label, blinded-endpoints trial. Lancet 2012; 379: 16131620 .

[16] Öztarhan K, Varlı YZ, Aktay Ayaz N. Usefulness of Kawasaki disease risk scoring systems to the Turkish population. Anatol J Cardiol. 2020; 24: 97-106.

[17] Davies S, Sutton N, Blackstock S, et al. Predicting IVIG resistance in UK Kawasaki disease. Arch Dis Child. 2015; 100: 366368 .

(Vágó Ildikó dr., Székesfehérvár, Seregélyesi út 3., 8000 e-mail: vagoildy@gmail.com)

A cikk a Creative Commons Attribution 4.0 International License (https://creativecommons.org/licenses/by/4.0/) feltételei szerint publikált Open Access közlemény, melynek szellemében a cikk bármilyen médiumban szabadon felhasználható, megosztható és újraközölhető, feltéve, hogy az eredeti szerző és a közlés helye, illetve a CC License linkje és az esetlegesen végrehajtott módosítások feltüntetésre kerülnek. (SID_1) 